Article

\title{
Experimental Study on Specific Heat of Concrete at High Temperatures and Its Influence on Thermal Energy Storage
}

\author{
Jianwen Pan ${ }^{1, *}$, Renxin Zou ${ }^{2}$ and Feng Jin ${ }^{1}$ \\ 1 State Key Laboratory of Hydroscience and Engineering, Tsinghua University, Beijing 100084, China; \\ jinfeng@tsinghua.edu.cn \\ 2 Huadong Engineering Corporation Limited, Hangzhou 311122, China; zourenxin@foxmail.com \\ * Correspondence: panjianwen@tsinghua.edu.cn; Tel.: +86-10-6278-6017
}

Academic Editor: Francesco Calise

Received: 18 September 2016; Accepted: 23 December 2016; Published: 29 December 2016

\begin{abstract}
Using concrete as a thermal energy storage (TES) material is a promising option for large-scale solar-thermal resource development and utilization. Specific heat is one of the most important characteristics for TES performance. In this paper, the half-open dynamic method based on the mixing principle is proposed and applied to measure concrete-specific heat at temperatures up to $600{ }^{\circ} \mathrm{C}$. Measurement of the specific heat of corundum ceramic $\left(99 \% \mathrm{Al}_{2} \mathrm{O}_{3}\right)$ is first performed, and the test results illustrate the accuracy and efficiency of the proposed test method. Furthermore, concrete-specific heat tests are carried out at high temperatures. It found that the specific heat increases as the temperature rises, especially, linearly in the range of $300-600{ }^{\circ} \mathrm{C}$, in which the concrete TES module is expected to be in operation. Finally, the effect of concrete-specific heat changes with temperature on its TES capacity is investigated, demonstrating that specific heat is of great significance for concrete TES design for concentrating solar power.
\end{abstract}

Keywords: concrete; specific heat; high temperature; thermal energy storage

\section{Introduction}

Clean energy is one of the most important trends around the world. Solar energy has received tremendous attention as it is clean, widespread, and inexhaustible. Thermal energy storage (TES) is crucial for solar thermal power plants-due to a lack of function at night or in poor weather conditions-and makes continuous stable electric energy output, which gives concentrating solar power (CSP) technology greater competitive strength.

The research group of the German Aerospace Center (DLR) has engaged in study on high-temperature solid-media energy storage since 2006 [1-4]. It has found that concrete is the most suitable solid-media material for high-temperature storage because of low investment and maintenance costs. Gil et al. [5] also found that concrete is the most promising candidate for solid sensible heat storage material due to its good thermal and mechanical properties and low cost. The material stability and storage performance have been verified in a $20-\mathrm{m}^{3}$ concrete module with more than 23 months of operation between 200 and $400{ }^{\circ} \mathrm{C}$ and more than 370 thermal cycles [4]. Salomoni et al. [6] have presented guidelines for designing a concrete storage module and its integration into a solar plant. Skinner et al. [7] have carried out experiments to study temperature parameters and physical properties of prismatic concrete with imbedded steel fin tubes between 400 and $500{ }^{\circ} \mathrm{C}$. John et al. [8] conducted thermal cycle tests of concrete and examined their residual compressive strengths which represent the structural stability of concrete. Wu et al. [9] have carried out a series of thermal cycling experiments to study the residual strength of ordinary concrete after exposure to high temperatures. These studies are 
focused on the mechanical properties of concrete exposed to high temperatures. However, study of the thermal storage capacity of concrete is also significant.

For thermal storage capacity, the specific heat, representing the energy that a unit mass of material needs to increase $1{ }^{\circ} \mathrm{C}$ of its temperature, is one of the most important parameters. During the last decade, a lot of work has been carried out on concrete-specific heat. Zhang et al. [10] summarized three methods for calorific properties testing: the conventional calorimetry method, the differential thermal analysis (DAT), and the differential scanning calorimetry (DSC) method. Besides, a simple method named T-history method was developed to measure the specific heat of phase-change materials. These methods require the sample to be homogeneous and of a very small size, and are therefore inappropriate for non-homogeneous and porous materials, such as concrete and rocks.

Pomainowski et al. [11] measured the specific heat of incorporated microencapsulated-PCM concrete with a new experimental method which used a hot plate and a cold plate to control the boundary temperature of concrete. Specific heat of concrete at room temperature $\left(17-31^{\circ} \mathrm{C}\right)$ was tested and it concluded that specific heat changes as the temperature alters. Choktaweekarn et al. [12] proposed a model for predicting the specific heat of fly-ash concrete. De Schutter and Taerwe [13] measured specific heat and thermal diffusivity of hardening concrete. Another approach presented by Bentz et al. [14], used the known specific heat of the various components of concrete along with the law of mixtures to determine the average specific heat of the non-homogeneous element. This approach provided satisfactory results.

The above-mentioned studies are mainly focused on measuring specific heat of mixed materials at room temperature, while there are few, if any, studies on the specific heat of concrete at high temperature (up to $600{ }^{\circ} \mathrm{C}$ ). High temperature specific heat of insulating brick has been measured by Long et al. [15] using the half-open dynamic method based on the mixing principle. It shows that the error is less than $6.3 \%$ when the method is calibrated with sapphire.

This paper aims at measuring specific heat of concrete at high temperatures and analyzing the influence of concrete specific heat on the thermal energy storage capacity during the charging and discharging process of TES. The rest of this paper is organized as follows: Section 2 first introduces the half-open dynamic method based on mixing principle for high temperature specific heat of large size and heterogeneous mixed material. Test material (concrete blocks) and calibrating material (corundum blocks) are then presented. Section 3 provides the test results and discussions. Section 4 analyzes the influence of temperature-based specific heat of concrete on thermal energy storage capacity of a fictitious concrete storage system, and finally Section 5 gives conclusions.

\section{Test Method and Material}

\subsection{Specific Heat Test Method}

\subsubsection{Half-Open Dynamic Method Based on Mixing Principle}

Mixing principle means immersing a high temperature specimen in water, and then the hot specimen releases heat and the water absorbs heat energy until a new thermal equilibrium is achieved. The specific heat can be calculated according to the initial temperatures of the hot specimen and water and the final thermal equilibrium temperature. Generally, the test requires adiabatic condition, which would be difficult for temperature measuring. A half-open dynamic method can solve this problem.

Putting some hot water $\left(\sim 73^{\circ} \mathrm{C}\right)$ into the insulated container whose top is kept open for convenient operation of the test. The water temperature falls with heat dissipation into the surroundings when it is higher than the environmental temperature. The observed water temperature declines linearly between $73-65{ }^{\circ} \mathrm{C}$ as shown in Figure 1. The slope of the temperature curve indicates the energy dissipation rate of the system. After the specimen is placed in the water, the slope of the water temperature curve is used to suggest the thermal equilibrium between water and the hot specimen. 


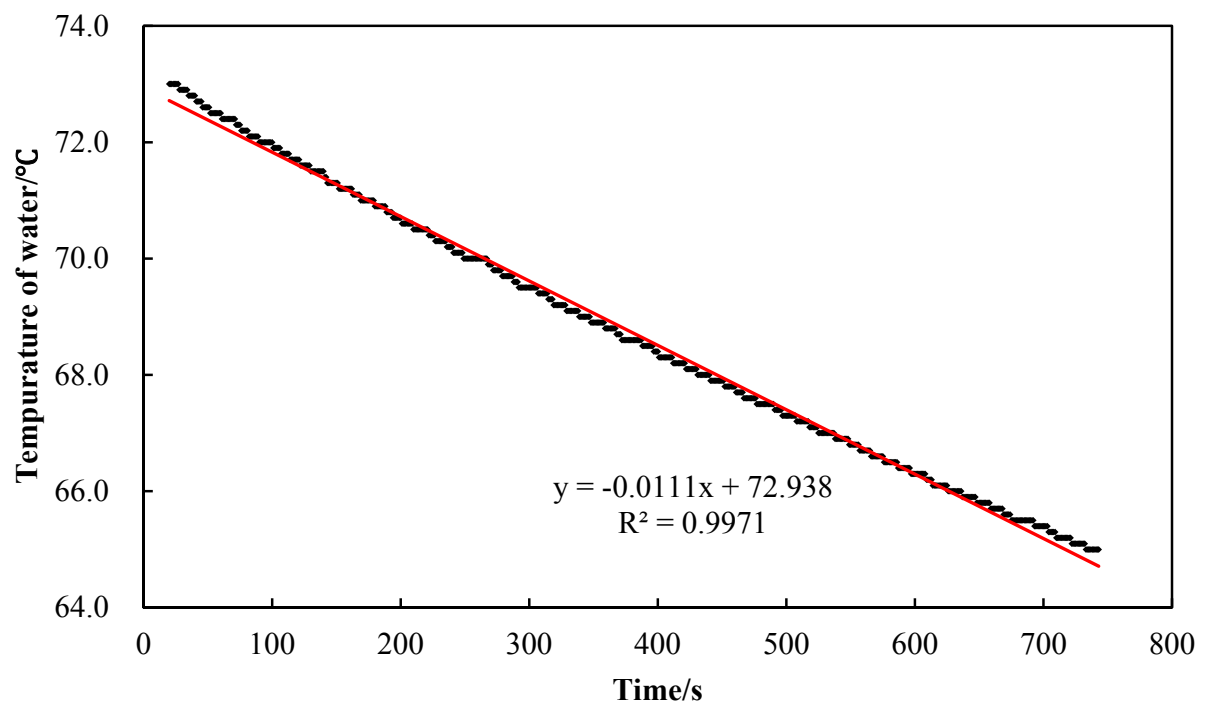

Figure 1. Temperature of water declines linearly between $73-65^{\circ} \mathrm{C}$.

\subsubsection{Test Device and Test Procedure}

Figure 2 schematically depicts the test system and the position of three thermometers. We heat distilled water which is contained in the opened insulated container to approximately $73{ }^{\circ} \mathrm{C}$ and start to record the changes of water temperature. Then we heat the specimen in the electric furnace until it reaches the required temperature $T_{1}$, and immerse the hot specimen into the water rapidly. The temperature recorder automatically measures and records the water temperature during the heat exchange process in the system. The changes of system mass are measured by the electronic quality recorder with the minimum resolution of $1.0 \mathrm{~g}$ and sampling acquisition frequency of $4.0 \mathrm{~Hz}$.

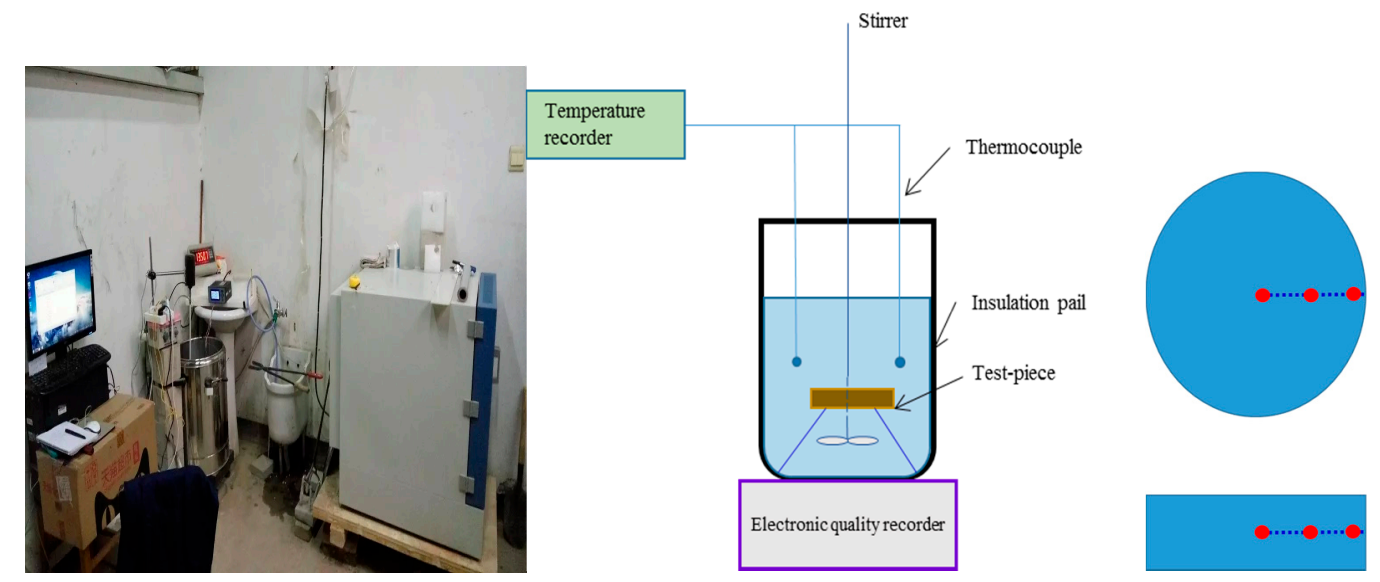

Figure 2. Schematic of test apparatus and position of temperature senor.

\subsubsection{Formula Derivation}

The water temperature varies during the test process is expected as shown in Figure 3. Before the hot specimen is placed in the water, the water temperature declines linearly (range $\mathrm{AB}$ ) due to heat released to the environment. Putting the hot specimen into water at point $B$, the water temperature rises until the system reaches a thermal equilibrium between the water and the specimen at point $C$ and then again declines linearly (range $C D$ ) as heat dissipates into the surroundings. As the specimen is placed in the water, the surrounding water rapidly reaches its boiling temperature, changing into 
gas, and escapes from the system. The reduction of water mass is measured using the electronic quality recorder.

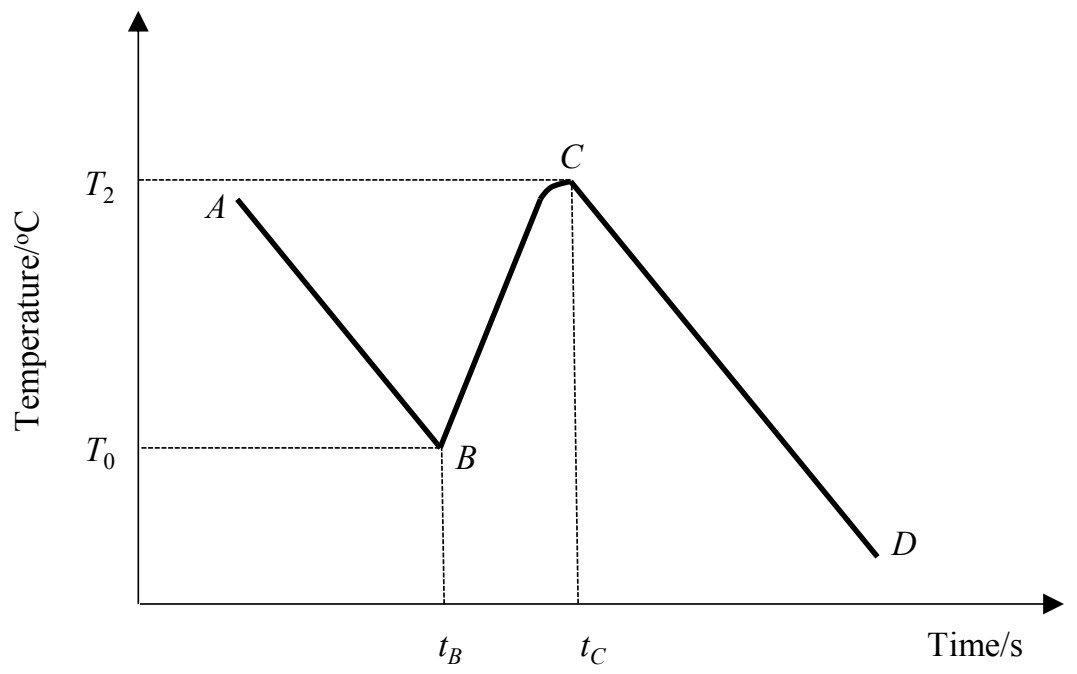

Figure 3. Water temperature changing process.

Considering thermal balance process of the system between point $B$ and $C$ in Figure 3, the thermal equilibrium equation is written as

$$
Q_{1}=Q_{2}+Q_{3}+Q_{4}
$$

where $Q_{1}$ represents the heat released from the hot specimen at range $\mathrm{BC} ; Q_{2}$ represents the heat absorbed by liquid water; $Q_{3}$ denotes the heat carried by vaporized water, and it is composed of the phase change energy and absorbed energy of the vaporized water; and $Q_{4}$ is the heat diffused to the environment. They can be expressed as follows

$$
\begin{gathered}
Q_{1}=m\left(c_{1} T_{1}-c_{2} T_{2}\right) \\
Q_{2}=c_{\text {wat }} m_{\text {wat }}\left(T_{2}-T_{0}\right) \\
Q_{3}=c_{\text {wat }} m_{b}\left(T_{b}-T_{0}\right)+k_{v} m_{b} \\
Q_{4}=c_{\text {wat }} m_{\text {wat }} k t_{b c}
\end{gathered}
$$

where the symbols' meaning is given in Table 1.

Table 1. Meaning of the symbols of Equations (2)-(5).

\begin{tabular}{cl}
\hline Symbol & Meaning \\
\hline$c_{i}$ & Specific heat of specimen at temperature $T_{i}, i=1,2$ \\
$m$ & Mass of specimen \\
$T_{0}$ & Water temperature when specimen is put in \\
$T_{1}$ & Specimen temperature when it is put into water \\
$T_{2}$ & Maximum achieved temperature of the system \\
$c_{w a t}$ & Specific heat of water, $4.2 \times 10^{3} \mathrm{~J} /(\mathrm{kg} \cdot \mathrm{K})$ \\
$m_{w a t}$ & Mass of liquid water \\
$m_{b}$ & Mass of vaporized water \\
$T_{b}$ & Temperature of boiling water, $100{ }^{\circ} \mathrm{C}$ \\
$k_{v}$ & Vaporization heat of water at $100{ }^{\circ} \mathrm{C}, 2.57 \times 10^{6} \mathrm{~J} / \mathrm{kg}$ \\
$k$ & Slope of range AB and range $\mathrm{CD}$ \\
$t_{b c}$ & Duration of range $\mathrm{BC}, t_{b c}=t_{C}-t_{B}$ \\
\hline
\end{tabular}


When the concrete specimen with a high temperature is put in water, only the water that directly contacts the specimen is observed to be vaporized in 3-5 s. The water does not boil due to sufficient amount of water in the container. The weight of the test system is automatically recorded by the electronic quality recorder with the sampling acquisition frequency of $4.0 \mathrm{~Hz}$ during the test, and its value at $10 \mathrm{~s}$ after the specimen put in water is selected to calculate the weight of vaporized water. Therefore, the weight of vaporized water is obtained as follows

$$
m_{b}=m_{0 \mathrm{~s}}+m-m_{10 \mathrm{~s}}
$$

where $m_{0 \mathrm{~s}}$ is the weight of the test system before the concrete specimen is put in water; $m_{10 \mathrm{~s}}$ is the weight of the test system at $10 \mathrm{~s}$ after the specimen is put in water, and $m$ denotes the weight of the concrete specimen with high temperature.

Combining Equation (1) and Equations (2)-(5), the specific heat of the specimen at temperature $T_{1}$ is obtained as follows

$$
c_{1}=\frac{c_{w a t} m_{w a t}\left(T_{2}-T_{0}+k t_{b c}\right)+c_{w a t} m_{b}\left(T_{b}-T_{0}\right)+k_{v} m_{b}+c_{2} m T_{2}}{m T_{1}}
$$

In order to obtain the specific heat $c_{1}$ at high temperature $T_{1}$, the specific heat $c_{2}$ at low temperature $\mathrm{T}_{2}$ is required. Changes of concrete specific heat at temperature in the range of 60 and $100{ }^{\circ} \mathrm{C}$ is small, and thus it is assumed constant between 60 and $100{ }^{\circ} \mathrm{C}$ in this study. Specific heat $c_{2}$ is then calculated:

$$
c_{2}=\frac{c_{w a t} m_{w a t}\left(T_{2}-T_{0}+k t_{b c}\right)+c_{w a t} m_{b}\left(T_{b}-T_{0}\right)+k_{v} m_{b}}{m\left(T_{1}-T_{2}\right)}
$$

The specific heat of specimen $c_{1}$ at high temperature can be obtained by substituting Equation (8) into Equation (7).

\subsection{Test Materials}

\subsubsection{Corundum Blocks}

Corundum blocks are used to verify accuracy of the proposed specific heat test system. The corundum block shown in Figure 4 a consists of $99 \mathrm{wt} \% \mathrm{Al}_{2} \mathrm{O}_{3}$, and its size is $100 \times 100 \times 7 \mathrm{~mm}^{3}$. The mass of the corundum block is $0.350 \mathrm{~kg}$.

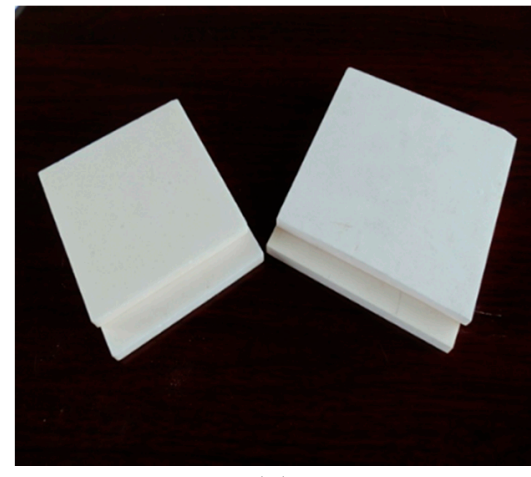

(a)

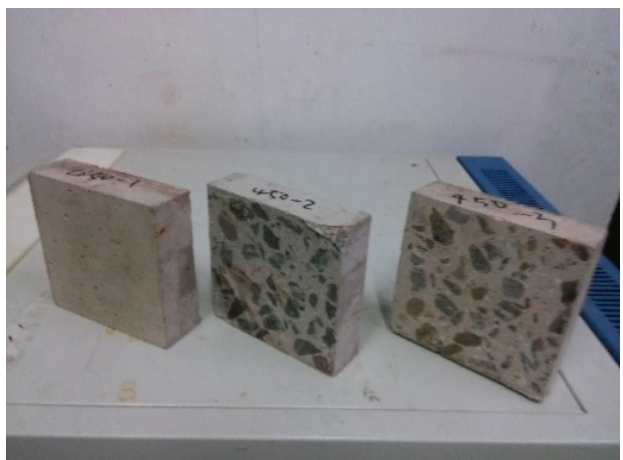

(b)

Figure 4. Test samples of corundum blocks and concrete blocks. (b) Concrete blocks.

\subsubsection{Concrete Material}

Ordinary concrete with compression strength of approximate $20 \mathrm{MPa}$ is considered in this study. The concrete mixture proportion is given in Table 2. Granite aggregate is used, and the polycarboxylate 
superplasticizer is applied in the concrete. Concrete blocks used in the specific heat test have the size of $150 \times 150 \times 45 \mathrm{~mm}^{3}$, which are cut from a standard concrete block $\left(150 \times 150 \times 150 \mathrm{~mm}^{3}\right)$. The concrete blocks are shown in Figure 4b.

Table 2. Mixture proportion of $1-\mathrm{m}^{3}$ concrete.

\begin{tabular}{|c|c|c|c|c|c|c|c|c|}
\hline $\begin{array}{c}\text { Cement } \\
(\mathrm{kg})\end{array}$ & $\begin{array}{l}\text { Fly Ash } \\
\text { (kg) }\end{array}$ & $\begin{array}{l}\text { Sand } \\
\text { (kg) }\end{array}$ & $\begin{array}{c}\text { Aggregate } \\
(5-20 \mathrm{~mm}) \\
(\mathrm{kg})\end{array}$ & $\begin{array}{c}\text { Aggregate } \\
(20-40 \mathrm{~mm}) \\
(\mathrm{kg})\end{array}$ & $\begin{array}{l}\text { Water } \\
(\mathbf{k g})\end{array}$ & $\begin{array}{c}\text { Superplasticizer } \\
(\mathbf{k g})\end{array}$ & $\begin{array}{c}\text { Air } \\
\text { Content }\end{array}$ & $\begin{array}{l}\text { Slump } \\
(\mathrm{mm})\end{array}$ \\
\hline 210.00 & 160.00 & 996.00 & 340.00 & 509.00 & 170.00 & 2.16 & $2.10 \%$ & 95.0 \\
\hline
\end{tabular}

\section{Test Results}

Nine groups of tests with different temperatures is designed in this study, including $100{ }^{\circ} \mathrm{C}$, $200{ }^{\circ} \mathrm{C}$, and ranges from 300 to $600{ }^{\circ} \mathrm{C}$ at increments of $50{ }^{\circ} \mathrm{C}$. Three specimens are used for one temperature case. The specimens are placed in a constant temperature electric furnace for $5 \mathrm{~h}$ until they achieve uniform temperature $T_{1}$. The initial quality of liquid water is $9.850 \pm 0.050 \mathrm{~kg}$ and its initial temperature is $65.0 \pm 0.5{ }^{\circ} \mathrm{C}$ when the specimens are put into the water in the opened insulated container.

\subsection{Corundum Blocks Test Result}

Table 3 lists the test results of the corundum blocks. Average value of the specific heat is calculated according to the tests of the three specimens under the same high temperature. Relative error between the test results and their average value is also given.

Table 3. Test data of the corundum blocks.

\begin{tabular}{|c|c|c|c|c|c|c|c|c|c|c|}
\hline Specimen & $\begin{array}{l}m \\
(\mathrm{~g})\end{array}$ & $\begin{array}{c}T_{1} \\
\left({ }^{\circ} \mathrm{C}\right)\end{array}$ & $\begin{array}{c}T_{0} \\
\left({ }^{\circ} \mathrm{C}\right)\end{array}$ & $\begin{array}{c}T_{2} \\
\left({ }^{\circ} \mathrm{C}\right)\end{array}$ & $\begin{array}{l}m_{\text {wat }} \\
\text { (g) }\end{array}$ & $\begin{array}{l}m_{b} \\
(\mathrm{~g})\end{array}$ & $\begin{array}{c}k \\
\left({ }^{\circ} \mathrm{C} / \mathrm{min}\right)\end{array}$ & $\begin{array}{c}c \\
(\mathrm{~J} /(\mathrm{kg} \cdot \mathrm{K}))\end{array}$ & $\begin{array}{c}\bar{c} \\
(\mathrm{~J} /(\mathrm{kg} \cdot \mathrm{K}))\end{array}$ & $\begin{array}{l}\text { Relative } \\
\text { Error (\%) }\end{array}$ \\
\hline GY100-1 & 353 & 100.0 & 64.5 & 64.9 & 3899 & 1 & 1.41 & 955 & \multirow{3}{*}{930} & 2.7 \\
\hline GY100-2 & 346 & 100.0 & 64.5 & 64.5 & 3903 & 1 & 1.60 & 898 & & 3.5 \\
\hline GY100-3 & 353 & 100.0 & 63.8 & 63.7 & 3919 & 1 & 1.31 & 938 & & 0.8 \\
\hline GY200-1 & 354 & 200.0 & 64.8 & 66.4 & 5126 & 3 & 1.10 & 1024 & \multirow{3}{*}{995} & 2.9 \\
\hline GY200-2 & 346 & 200.0 & 64.9 & 66.3 & 5118 & 2 & 1.02 & 975 & & 2.0 \\
\hline GY200-3 & 353 & 200.0 & 64.8 & 66.2 & 5112 & 3 & 1.10 & 987 & & 0.8 \\
\hline GY300-1 & 347 & 300.0 & 64.9 & 66.6 & 9844 & 4 & 0.58 & 1093 & \multirow{3}{*}{1087} & 0.6 \\
\hline GY300-2 & 344 & 300.0 & 64.9 & 66.6 & 9853 & 4 & 0.55 & 1088 & & 0.1 \\
\hline GY300-3 & 342 & 300.0 & 65.0 & 66.6 & 9855 & 4 & 0.55 & 1080 & & 0.6 \\
\hline GY350-1 & 353 & 350.0 & 64.6 & 66.7 & 9831 & 7 & 0.52 & 1125 & \multirow{3}{*}{1125} & 0.0 \\
\hline GY350-2 & 352 & 350.0 & 64.5 & 66.5 & 9832 & 7 & 0.52 & 1125 & & 0.0 \\
\hline GY350-3 & 348 & 350.0 & 64.4 & 66.3 & 9834 & 8 & 0.51 & 1125 & & 0.0 \\
\hline GY400-1 & 343 & 400.0 & 65.0 & 67.2 & 9849 & 7 & 0.54 & 1097 & \multirow{3}{*}{1124} & 2.4 \\
\hline GY400-2 & 341 & 400.0 & 64.7 & 67.2 & 9845 & 5 & 0.56 & 1112 & & 1.0 \\
\hline GY400-3 & 349 & 400.0 & 64.9 & 67.3 & 9841 & 9 & 0.55 & 1162 & & 3.4 \\
\hline GY450-1 & 354 & 450.0 & 64.9 & 67.3 & 9832 & 12 & 0.60 & 1109 & \multirow{3}{*}{1141} & 2.8 \\
\hline GY450-2 & 353 & 450.0 & 65.0 & 67.8 & 9837 & 9 & 0.56 & 1150 & & 0.8 \\
\hline GY450-3 & 346 & 450.0 & 64.5 & 67.4 & 9833 & 7 & 0.52 & 1163 & & 2.0 \\
\hline GY500-1 & 354 & 500.0 & 65.0 & 68.1 & 9911 & 11 & 0.55 & 1165 & \multirow{3}{*}{1160} & 0.5 \\
\hline GY500-2 & 344 & 500.0 & 65.1 & 68.0 & 9892 & 12 & 0.55 & 1137 & & 2.0 \\
\hline GY500-3 & 354 & 500.0 & 64.6 & 67.8 & 9905 & 11 & 0.54 & 1177 & & 1.5 \\
\hline GY550-1 & 342 & 550.0 & 64.6 & 68.1 & 9832 & 10 & 0.60 & 1174 & \multirow{3}{*}{1188} & 1.2 \\
\hline GY550-2 & 357 & 550.0 & 65.0 & 68.6 & 9830 & 15 & 0.56 & 1205 & & 1.4 \\
\hline GY550-3 & 352 & 550.0 & 65.1 & 68.6 & 9843 & 12 & 0.55 & 1186 & & 0.2 \\
\hline GY600-1 & 357 & 600.0 & 65.0 & 69.2 & 9874 & 14 & 0.59 & 1211 & \multirow{3}{*}{1210} & 0.1 \\
\hline GY600-2 & 344 & 600.0 & 65.0 & 68.8 & 9865 & 14 & 0.59 & 1217 & & 0.6 \\
\hline GY600-3 & 346 & 600.0 & 65.0 & 69.2 & 9860 & 12 & 0.56 & 1201 & & 0.7 \\
\hline
\end{tabular}


The temperature variable curves of water during the test for three corundum blocks exposed to $300{ }^{\circ} \mathrm{C}$ and $400{ }^{\circ} \mathrm{C}$ are illustrated in Figure 5. Before the specimens are put into the water, the temperature declines linearly due to heat diffused to the environment. The temperature rapidly increases from about 65.0 to $66.6^{\circ} \mathrm{C}$ and $67.3^{\circ} \mathrm{C}$ for the cases of 300 and $400{ }^{\circ} \mathrm{C}$, respectively. The system takes approximately $40 \mathrm{~s}$ to achieve thermal equilibrium between the water and the corundum block, and then the temperature again decreases linearly.

The mass variable curves of the system are shown in Figure 6. The measured curves for the three specimens are close. When the specimen is placed into the water, the system mass shows an instantaneous increase of $0.350 \mathrm{~kg}$ which is the weight of a corundum block.

Figure 7 shows the specific heat of corundum blocks measured from the tests. Close test results are obtained for three specimens with less than 3.5\% relative error between the test values and their average, indicating repeatability and reliability of the experiment for the same case. The specific heat standard values of $\mathrm{Al}_{2} \mathrm{O}_{3}$ at different high temperatures provided by the National Institute of Standards and Technology (NIST) [16] are employed to validate the proposed test method. It is found that the test result is in good agreement with the NIST standard value, and good accuracy of the test method is demonstrated.

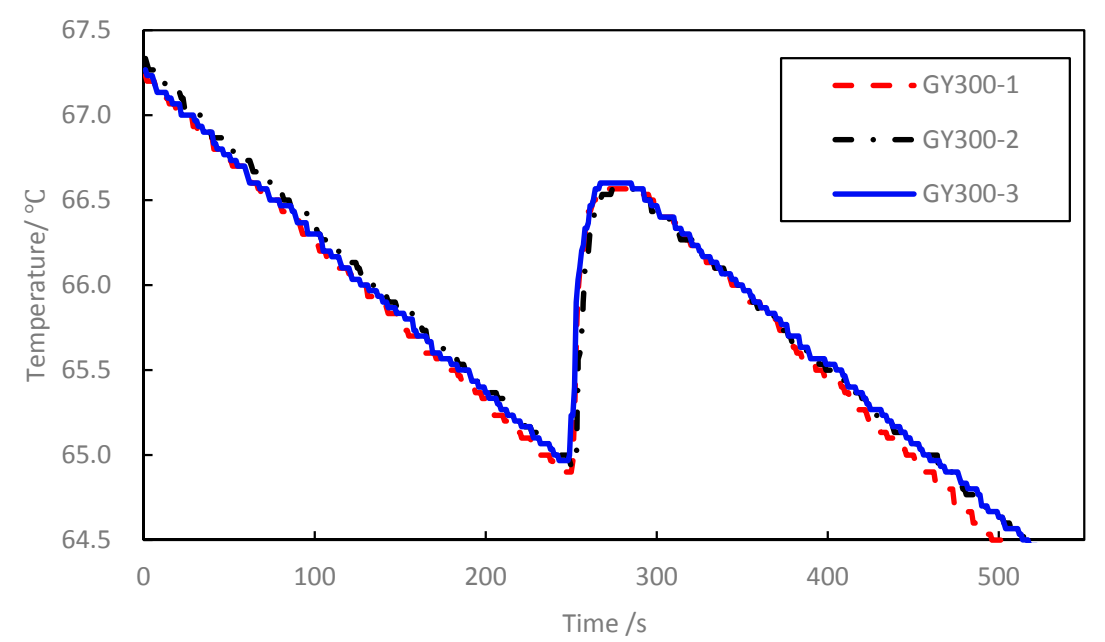

(a)

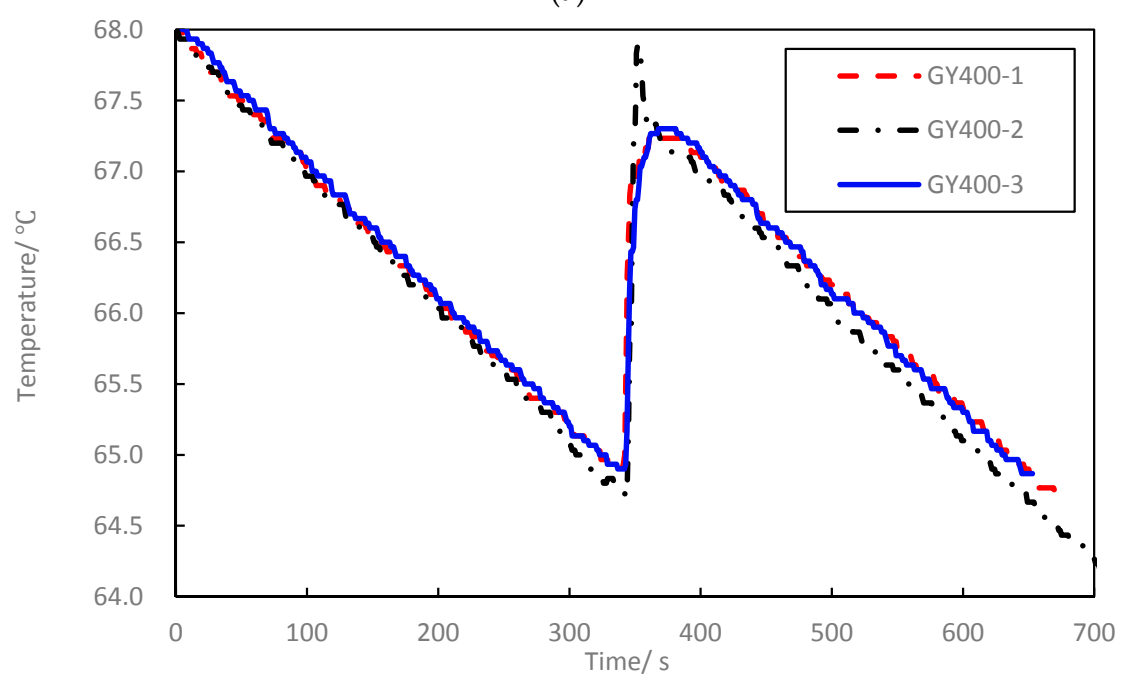

(b)

Figure 5. Temperature variable curve of water in the test for corundum. (a) $300{ }^{\circ} \mathrm{C}$; (b) $400{ }^{\circ} \mathrm{C}$. 


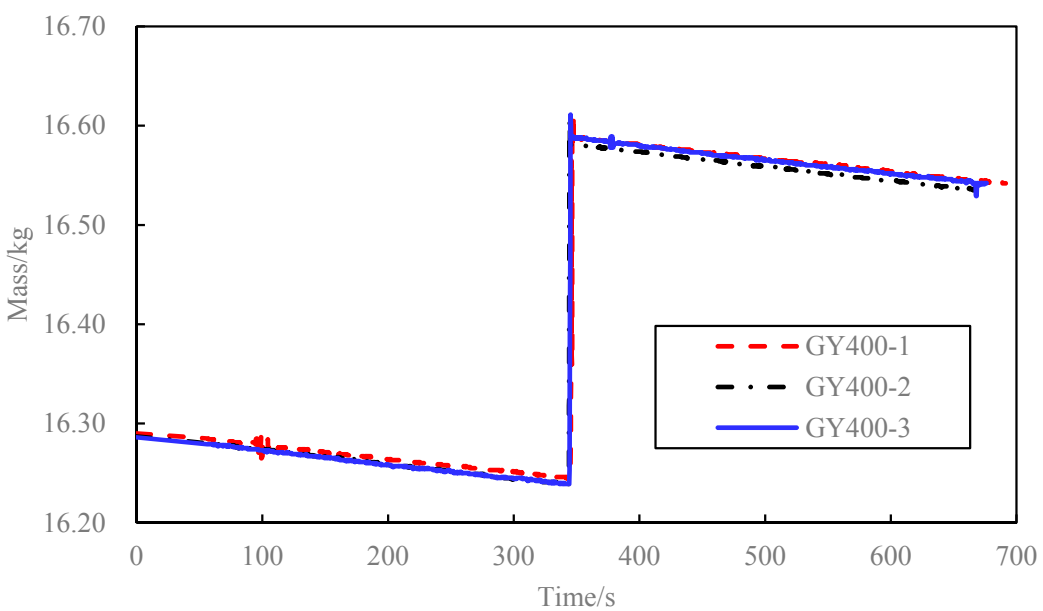

(a)

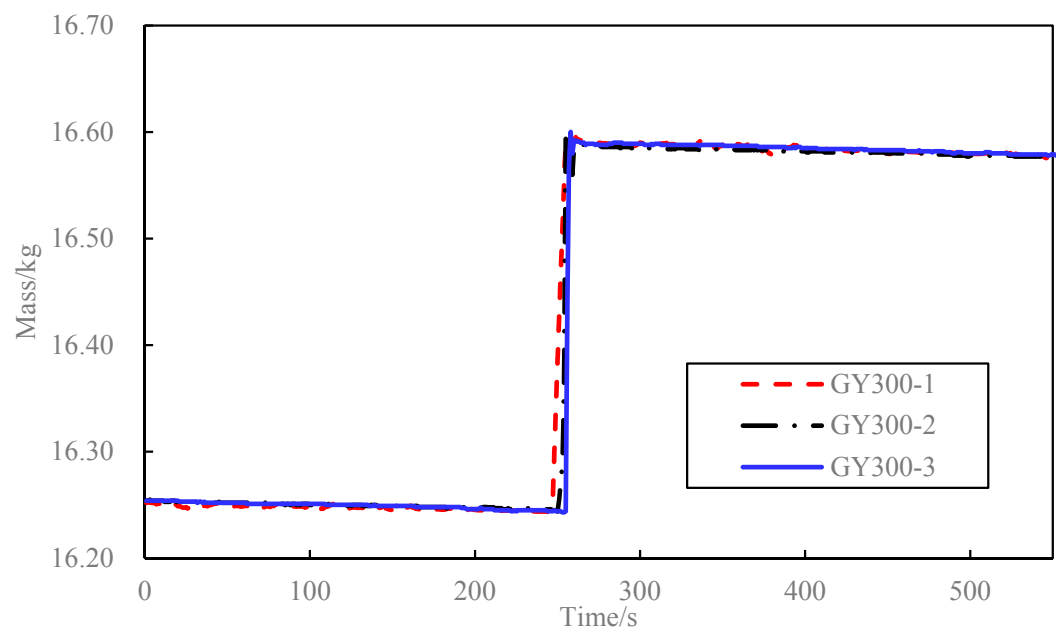

(b)

Figure 6. Mass variable curve of the system in the test for corundum. (a) $300{ }^{\circ} \mathrm{C}$; (b) $400{ }^{\circ} \mathrm{C}$.

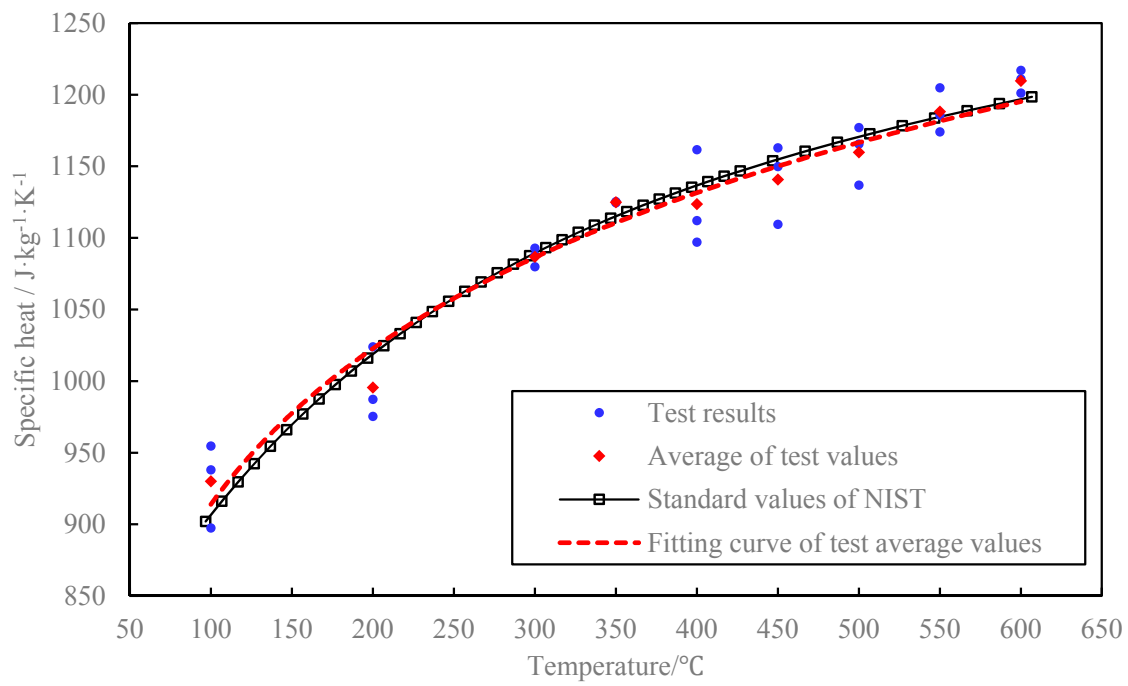

Figure 7. Comparison of specific heat of corundum between test results and standard values of NIST [16]. 


\subsection{Concrete Blocks Test Result}

Table 4 gives the test data of the experiments along with the average value of the specific heat obtained from the three specimens under the same temperature and the relative error of each test.

Table 4. Test data of the concrete specimens.

\begin{tabular}{|c|c|c|c|c|c|c|c|c|c|c|}
\hline Specimen & $\begin{array}{l}M \\
(\mathrm{~g})\end{array}$ & $\begin{array}{c}T_{1} \\
\left({ }^{\circ} \mathrm{C}\right)\end{array}$ & $\begin{array}{c}T_{0} \\
\left({ }^{\circ} \mathrm{C}\right)\end{array}$ & $\begin{array}{c}T_{2} \\
\left({ }^{\circ} \mathrm{C}\right)\end{array}$ & $\begin{array}{c}m_{w a t} \\
(\mathrm{~g})\end{array}$ & $\begin{array}{l}m_{b} \\
(\mathrm{~g})\end{array}$ & $\begin{array}{c}k \\
\left({ }^{\circ} \mathrm{C} / \mathrm{min}\right)\end{array}$ & $\begin{array}{c}c \\
(\mathrm{~J} /(\mathrm{kg} \cdot \mathrm{K}))\end{array}$ & $\begin{array}{c}\bar{c} \\
(\mathrm{~J} /(\mathrm{kg} \cdot \mathrm{K}))\end{array}$ & $\begin{array}{l}\text { Relative } \\
\text { Error (\%) }\end{array}$ \\
\hline HNT100-1 & 2532 & 100.0 & 65.0 & 65.8 & 9515 & 14 & 0.47 & 848 & \multirow{3}{*}{832} & 2.0 \\
\hline HNT100-2 & 2526 & 100.0 & 64.7 & 65.5 & 9527 & 11 & 0.46 & 821 & & 1.3 \\
\hline HNT100-3 & 2495 & 100.0 & 65.0 & 65.4 & 9525 & 16 & 0.46 & 826 & & 0.7 \\
\hline HNT200-1 & 2284 & 200.0 & 65.5 & 67.7 & 9996 & 48 & 0.51 & 892 & \multirow{3}{*}{903} & 1.3 \\
\hline HNT200-2 & 2433 & 200.0 & 65.0 & 68.4 & 9989 & 48 & 0.52 & 904 & & 0.1 \\
\hline HNT200-3 & 2613 & 200.0 & 65.0 & 68.5 & 9984 & 49 & 0.52 & 914 & & 1.2 \\
\hline HNT300-1 & 2068 & 300.0 & 65.0 & 68.0 & 19,790 & 66 & 0.26 & 1064 & \multirow{3}{*}{1058} & 0.6 \\
\hline HNT300-2 & 2553 & 300.0 & 65.0 & 68.9 & 19,809 & 69 & 0.26 & 1043 & & 1.4 \\
\hline HNT300-3 & 2578 & 300.0 & 65.0 & 69.1 & 19,783 & 72 & 0.27 & 1066 & & 0.8 \\
\hline HNT350-1 & 2377 & 350.0 & 65.0 & 69.8 & 19,783 & 77 & 0.27 & 1080 & \multirow{3}{*}{1078} & 0.2 \\
\hline HNT350-2 & 2441 & 350.0 & 65.0 & 69.8 & 19,786 & 76 & 0.27 & 1061 & & 1.6 \\
\hline HNT350-3 & 2289 & 350.0 & 65.0 & 69.7 & 19,783 & 74 & 0.27 & 1093 & & 1.4 \\
\hline HNT400-1 & 2312 & 400.0 & 65.1 & 70.9 & 19,763 & 81 & 0.29 & 1096 & \multirow{3}{*}{1095} & 0.1 \\
\hline HNT400-2 & 2397 & 400.0 & 65.1 & 70.6 & 19,767 & 99 & 0.28 & 1093 & & 0.2 \\
\hline HNT400-3 & 2352 & 400.0 & 65.0 & 70.8 & 19,757 & 84 & 0.28 & 1097 & & 0.2 \\
\hline HNT450-1 & 2427 & 450.0 & 65.0 & 72.2 & 19,762 & 96 & 0.29 & 1096 & \multirow{3}{*}{1112} & 1.5 \\
\hline HNT450-2 & 2223 & 450.0 & 65.0 & 71.7 & 19,753 & 92 & 0.29 & 1128 & & 1.4 \\
\hline HNT450-3 & 2520 & 450.0 & 65.0 & 72.5 & 19,743 & 105 & 0.29 & 1113 & & 0.1 \\
\hline HNT500-1 & 2.276 & 500.0 & 65.0 & 72.6 & 19,768 & 100 & 0.29 & 1102 & \multirow{3}{*}{1126} & 2.2 \\
\hline HNT500-2 & 2.436 & 500.0 & 65.0 & 73.3 & 19,742 & 116 & 0.28 & 1133 & & 0.6 \\
\hline HNT500-3 & 2.396 & 500.0 & 65.0 & 73.4 & 19,741 & 113 & 0.28 & 1144 & & 1.6 \\
\hline HNT550-1 & 2346 & 550.0 & 65.0 & 74.5 & 19,737 & 120 & 0.29 & 1148 & \multirow{3}{*}{1141} & 0.6 \\
\hline HNT550-2 & 2421 & 550.0 & 65.0 & 74.4 & 19,734 & 122 & 0.29 & 1116 & & 2.2 \\
\hline HNT550-3 & 2184 & 550.0 & 65.0 & 74.1 & 19,744 & 110 & 0.29 & 1160 & & 1.6 \\
\hline HNT600-1 & 2411 & 600.0 & 65.0 & 75.5 & 19,695 & 142 & 0.31 & 1146 & \multirow{3}{*}{1164} & 1.5 \\
\hline HNT600-2 & 2218 & 600.0 & 64.9 & 74.6 & 19,719 & 134 & 0.32 & 1167 & & 0.3 \\
\hline HNT600-3 & 2260 & 600.0 & 65.1 & 75.1 & 19,721 & 137 & 0.32 & 1178 & & 1.2 \\
\hline
\end{tabular}

Figures 8 and 9 show the temperature and mass variable curves of the test system for high temperature specific heat measurement of concrete, respectively. The variation of the temperature and mass is similar with those observed from the test of corundum. In the same temperature test case, the water has a higher temperature when it reaches thermal balance due to the concrete block with greater weight containing more energy.

The high-temperature specific heat of concrete blocks measured from the tests is shown in Figure 10. The test values of specific heat of the three specimens for the same temperature case is close, and the relative error between them and their average value is smaller than $2.2 \%$.

The specific heat of concrete increases as its temperature rises, which is shown in Figure 10. Especially, it increases linearly at temperatures in the range of $300-600{ }^{\circ} \mathrm{C}$, in which a concrete thermal energy storage system is expected to be in operation. The specific heat of concrete at temperature $300{ }^{\circ} \mathrm{C}$ is about $1055 \mathrm{~J} /(\mathrm{kg} \cdot \mathrm{K})$, while it shows an increase of $10.0 \%$ at $600{ }^{\circ} \mathrm{C}$. For general estimation of the thermal energy storage capacity of concrete, a formula for specific heat is given according to the test results:

$$
c(T)=0.3403 T+957.55, \quad T \in[300,600]
$$

where $c$ is the concrete specific heat which is measured in $\mathrm{J} /(\mathrm{kg} \cdot \mathrm{K}) ; T$ is the temperature with units of ${ }^{\circ} \mathrm{C} . R^{2}=0.9964$ approaches 1.0 , and thus the regression equations are reasonable for fitting the experimental data. 
It is noteworthy that thermal energy storage experiences a charging and discharging process and cracks would appear in concrete. The cracks may not change the components and mass of concrete, and thus there is no effect of cracks on the specific heat according to its definition. However, the cracks would vary the conductivity of concrete and significantly change the heat transfer behavior. It brings forward another important issue for thermal storage, which needs further study.

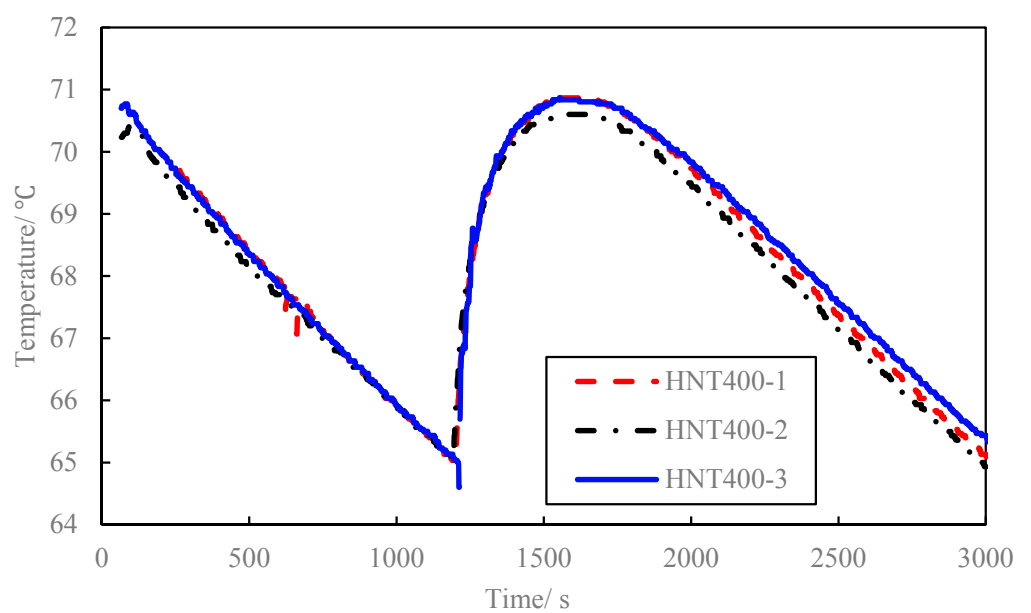

(a)

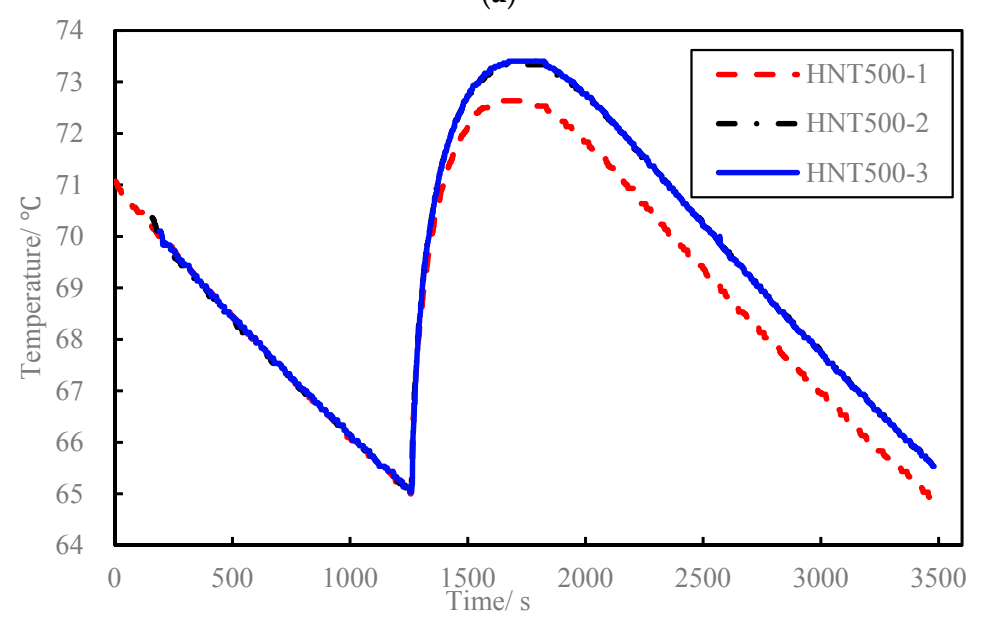

(b)

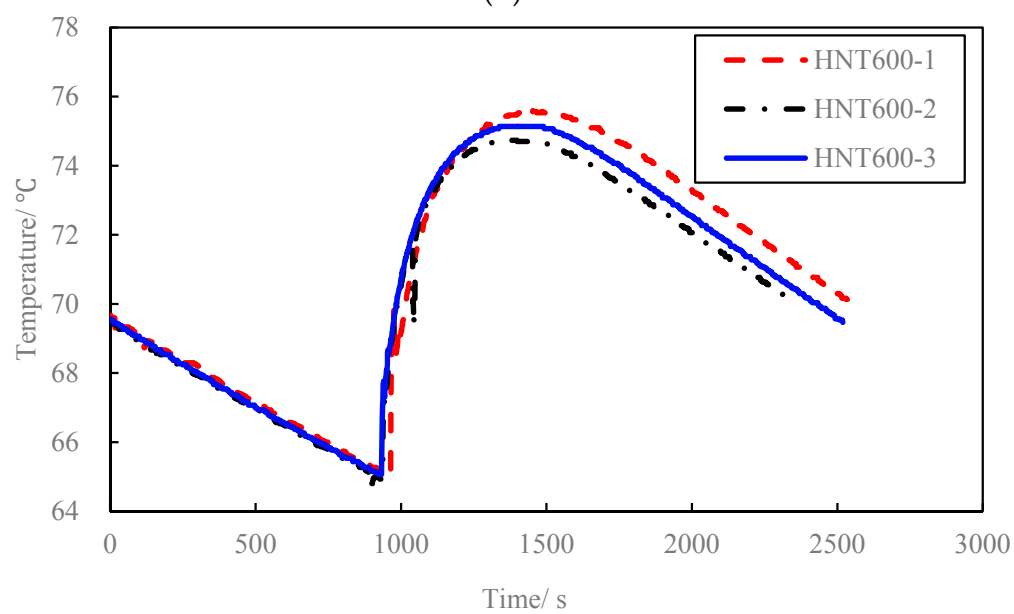

(c)

Figure 8. Temperature variable curve of water in the test for concrete. (a) $300{ }^{\circ} \mathrm{C}$; (b) $400{ }^{\circ} \mathrm{C}$; (c) $500{ }^{\circ} \mathrm{C}$. 


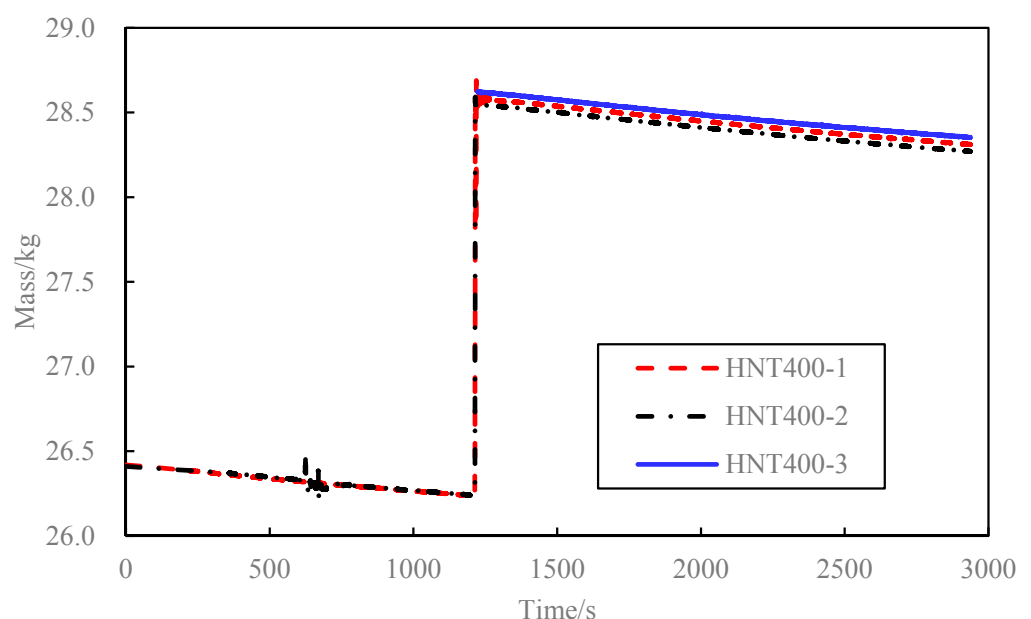

(a)

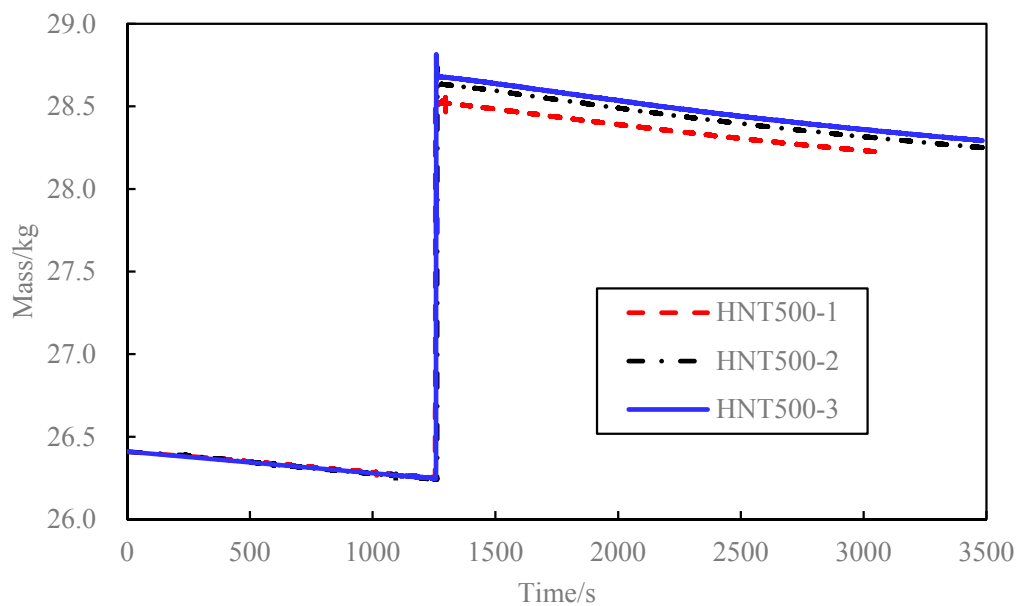

(b)

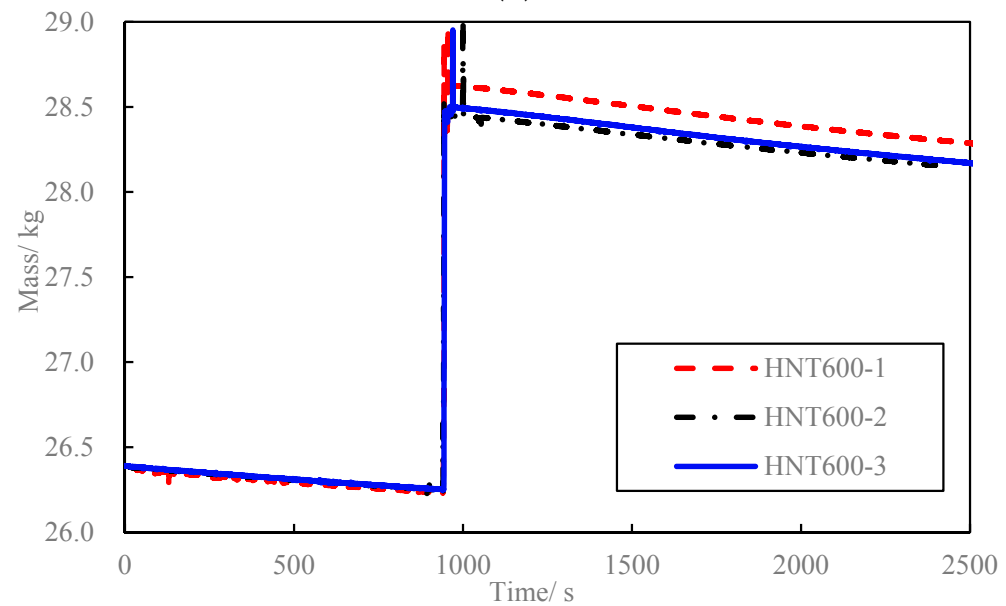

(c)

Figure 9. Mass variable curve of the system in the test for corundum. (a) $300{ }^{\circ} \mathrm{C}$; (b) $400{ }^{\circ} \mathrm{C}$; (c) $500{ }^{\circ} \mathrm{C}$. 


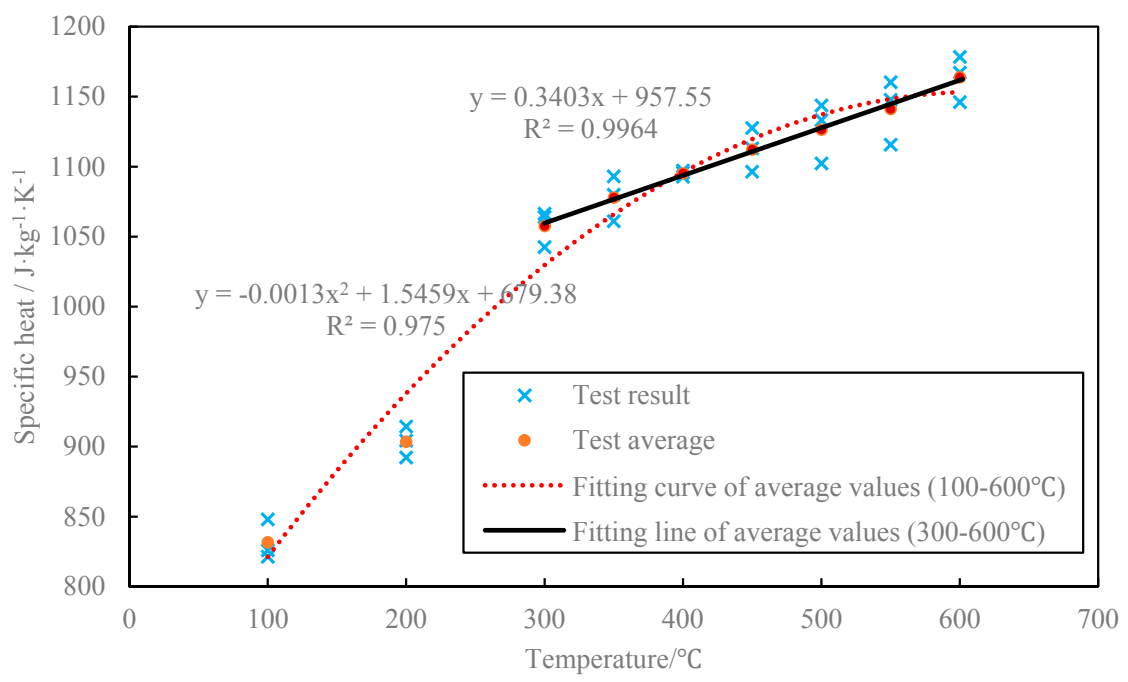

Figure 10. Test result of concrete specific heat at high temperatures.

\section{Influence of Concrete Specific Heat on TES Capacity}

According to the test results, concrete has a variable specific heat at different temperatures, which we called temperature-based concrete specific heat. When temperature increases from $T_{0}$ to $T$, the heat that concrete needs to absorb is expressed as follows:

$$
E_{s t o}=\mathrm{c}(T) m T-c\left(T_{0}\right) m T_{0}
$$

where $E_{\text {sto }}$ is the thermal energy stored in concrete; $m$ is the mass of concrete; and $c(T)$ is the temperature-based concrete specific heat, i.e., specific heat of concrete at temperature $T$.

Thermal energy storage capacity is one of the most important issues when concrete storage module is designed for CSP plants. Concrete thermal energy storage system is in operation with charging and discharging between high and low temperatures, which results in a variable specific heat of concrete and energy storage capacity of the system. Therefore, the influence of temperature-based concrete specific heat on energy storage capacity of CSP plants must be included in order to produce accurate results.

A 50,000 $\mathrm{m}^{3}$ concrete storage module with $1100-\mathrm{MWh}$ capacity for a virtual $50 \mathrm{MW}_{\mathrm{el}}$ parabolic trough power plant, designed by Laing et al. [4], is considered herein. The concrete density is approximately $2250 \mathrm{~kg} / \mathrm{m}^{3}$, and thus the mass of the concrete storage module is about $1.125 \times 10^{8} \mathrm{~kg}$. The concrete storage module is assumed to be charging and discharging between 300 and $400{ }^{\circ} \mathrm{C}$ as shown in Figure 11.

Heat storage in the concrete storage module can be calculated according to Equation (10). Figure 12 displays the thermal energy storage capacity of the system within three thermal cycles. For comparison, three cases are considered, i.e., (i) temperature-based concrete specific heat defined by Equation (9); (ii) average value of concrete specific heat at temperatures between 300 and $400{ }^{\circ} \mathrm{C}$; and (iii) concrete specific heat at room temperature. The thermal energy storage of the system varies with temperature changes. The case of temperature-based concrete specific heat shows the most thermal energy storage capacity, which is $10 \%$ larger than that from the case of average specific heat and $40 \%$ greater than that from the case of room-temperature specific heat. Therefore, understanding concrete specific heat at high temperatures and its changes with temperature are of significance to thermal energy storage capacity design for solar-thermal power stations. Using the temperature-based concrete specific heat to design a concrete storage module may obtain a more realistic thermal energy storage capacity for the system. 


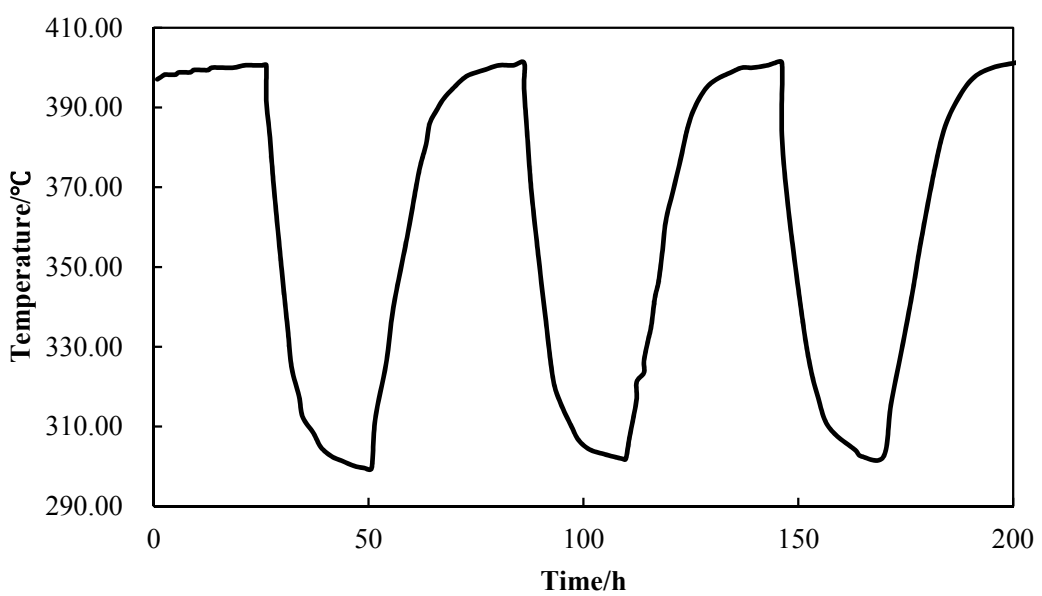

Figure 11. Designed temperature process of concrete storage module during charging and discharging processes.

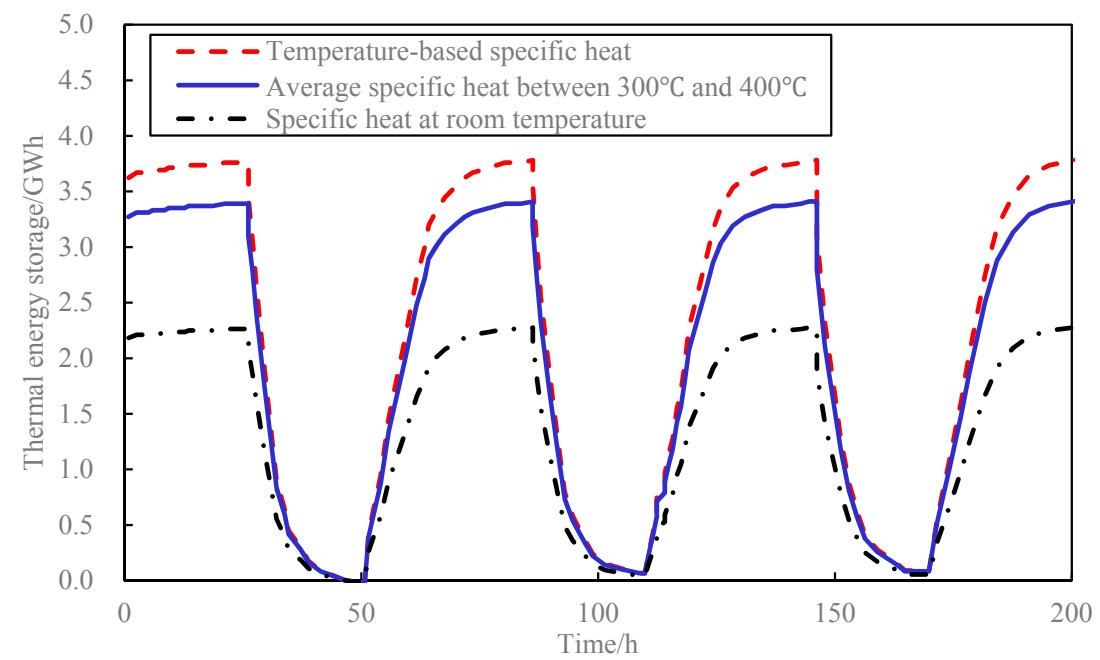

Figure 12. Influence of specific heat on thermal energy storage capacity of the concrete module.

\section{Conclusions}

In this paper, the half-open dynamic method based on mixing principle is proposed to measure concrete-specific heat at high temperatures (up to $600^{\circ} \mathrm{C}$ ). The effect of temperature-based concrete-specific heat on thermal energy storage capacity of concrete storage module is presented.

The half-open dynamic method based on the mixing principle is calibrated by measuring the specific heat of corundum $\left(\mathrm{Al}_{2} \mathrm{O}_{3}\right)$ at high temperatures and comparing the test results with its standard values provided by NIST. It shows that the proposed test method has good accuracy and efficiency on measurement of specific heat of heterogeneous (concrete or rocks) at high temperatures.

The proposed test method is applied to measure specific heat of concrete at high temperatures. The specific heat of concrete increases as its temperature rises, especially, linearly in the range of 300 and $600{ }^{\circ} \mathrm{C}$, in which concrete thermal energy storage module is expected to be in operation. The specific heat of concrete at temperature $300{ }^{\circ} \mathrm{C}$ is about $1055 \mathrm{~J} /(\mathrm{kg} \cdot \mathrm{K})$, while it shows an increase of $10.0 \%$ at $600{ }^{\circ} \mathrm{C}$.

Concrete thermal energy storage modules are in operation with charging and discharging between high and low temperatures, which results in variable concrete specific heat and energy storage capacity of the system. Using the temperature-based concrete-specific heat to design the concrete storage module provides a more realistic thermal energy storage capacity for solar-thermal power plants. 
Acknowledgments: This work was supported by the Tsinghua University Initiative Scientific Research Program (No. 20151080439) and the National Natural Science Foundation of China (No. 51579133).

Author Contributions: Jianwen Pan and Feng Jin conceived the experiments; Renxin Zou designed and performed the experiments; Jianwen Pan and Renxin Zou analyzed the data and wrote the paper.

Conflicts of Interest: The authors declare no conflict of interest.

\section{References}

1. Laing, D.; Steinmann, W.; Tamme, R.; Richterb, C. Solid media thermal storage for parabolic trough power plants. Sol. Energy 2006, 80, 1283-1289. [CrossRef]

2. Laing, D.; Steinmann, W.D.; Fiss, M.; Tamme, R.; Brand, T.; Bahl, C. Solid media thermal storage development and analysis of modular storage operation concepts for parabolic trough power plants. J. Sol. Energy Eng. 2008, 130, 1-5. [CrossRef]

3. Laing, D.; Lehmann, D.; Fiss, M.; Bahl, C. Test Results of Concrete Thermal Energy Storage for Parabolic Trough Power Plants. J. Sol. Energy Eng.-Trans. ASME 2009, 131, 0410074. [CrossRef]

4. Laing, D.; Bahl, C.; Bauer, T.; Fiss, M.; Breidenbach, N.; Hempel, M. High-Temperature Solid-Media Thermal Energy Storage for Solar Thermal Power Plants. Proc. IEEE 2012, 100, 516-524. [CrossRef]

5. Gil, A.; Medrano, M.; Martorell, I.; Lázaro, A.; Dolado, P.; Zalba, B.; Cabeza, L.F. State of the art on high temperature thermal energy storage for power generation. Part 1 -Concepts, materials and modellization. Renew. Sustain. Energy Rev. 2010, 14, 31-55. [CrossRef]

6. Salomoni, V.A.; Majorana, C.E.; Giannuzzi, G.M.; Miliozzi, A.; di Maggio, R.; Girardi, F.; Mele, D.; Lucentini, M. Thermal storage of sensible heat using concrete modules in solar power plants. Sol. Energy 2014, 103, 303-315. [CrossRef]

7. Skinner, J.E.; Strasser, M.N.; Brown, B.M.; Selvam, R.P. Testing of High-Performance Concrete as a Thermal Energy Storage Medium at High Temperatures. J. Sol. Energy Eng.-Trans. ASME 2014, 136, 0210042.

8. John, E.; Hale, M.; Selvam, P. Concrete as a thermal energy storage medium for thermocline solar energy storage systems. Sol. Energy 2013, 96, 194-204. [CrossRef]

9. Wu, C.; Pan, J.; Zhong, W.; Jin, F. Testing of high thermal cycling stability of low strength concrete as a thermal energy storage material. Appl. Sci. 2016, 6, 271. [CrossRef]

10. Zhang, Y.P.; Jiang, Y.; Jiang, Y. A simple method, the T-history method, of determining the heat of fusion, specific heat and thermal conductivity of phase-change materials. Meas. Sci. Technol. 1999, 10, 201-205.

11. Pomianowski, M.; Heiselberg, P.; Jensen, R.L.; Cheng, R.; Zhang, Y. A new experimental method to determine specific heat capacity of inhomogeneous concrete material with incorporated microencapsulated-PCM. Cem. Concr. Res. 2014, 22-34. [CrossRef]

12. Choktaweekarn, P.; Saengsoy, W.; Tangtermsirikul, S. A model for predicting the specific heat capacity of fly-ash concrete. ScienceAsia 2009, 35, 178-182. [CrossRef]

13. De Schutter, G.; Taerwe, L. Specific heat and thermal diffusivity of hardening concrete. Mag. Concr. Res. 1995, 47, 203-208. [CrossRef]

14. Bentz, D.P.; Peltz, M.A.; Duran-Herrera, A.; Valdez, P.; Juarez, C.A. Thermal properties of high-volume fly ash mortars and concretes. J. Build. Phys. 2011, 34, 263-275. [CrossRef]

15. Long, H.; Lu, Y.; Kang, J.; Nie, G.; Ma, B.; Fu, L. Measurement of specific heat capacity of insulating brick at high temperatures by a half-open dynamic method based on hybrid principle. Foundry 2011, 60, 1222-1225.

16. National Bureau of Standards (NBS). National Bureau of Standards Certificate Standard Reference Material 720, Synthetic Sapphire $\left(\mathrm{Al}_{2} \mathrm{O}_{3}\right)$; U.S. Department of Commerce: Washington, DC, USA, 1982.

(C) 2016 by the authors; licensee MDPI, Basel, Switzerland. This article is an open access article distributed under the terms and conditions of the Creative Commons Attribution (CC-BY) license (http:/ / creativecommons.org/licenses/by/4.0/). 